\title{
Translation Errors Made by Indonesian-English Translators in Crowdsourcing Translation Application
}

\author{
Zainar M Salam \\ zain.arr81@gmail.com \\ Mansur Akil \\ mansur.akil@unm.ac.id \\ Andi Qashas Rahman \\ qashas54@gmail.com \\ Graduate Program \\ State University of Makassar, Indonesia
}

\begin{abstract}
The research aims to describe the kinds of translation errors made by Indonesian-English translators in crowdsourcing translation application and the dominant kind of translation errors made by Indonesian-English translators in crowdsourcing translation application. The problem statements of the research are (1) What kinds of translation errors made by Indonesian-English translators in crowdsourcing translation application? (2) What is dominant kind of translation error made by Indonesian-English translators in crowdsourcing translation application?. The method used on the research was descriptive qualitative. The subject of the research was the Indonesian-English translators of crowdsourcing translation application. The researcher took 50 Indonesian-English translation requests (source language texts) and all of its' translations in English (target language texts) from the crowdsourcing translation application to find out the translation errors. Then the researcher classified them into 5 kinds of translation errors. The results of the research revealed that there were 50 source language texts that translated into 353 target language texts with 350 variations of translation in total. There were 75 translation errors in total or $21.25 \%$ from all if the 353 target language texts. There were $3(0,85 \%)$ translation errors in inversion of meaning, $11(3.12 \%)$ translation errors in omission of meaning, $8(2.27 \%)$ translation errors in addition of meaning, $44(12.46 \%)$ translation errors in deviation of meaning, and 9 $(2.55 \%)$ in modification of meaning. Dominant kind of the translation error that the Indonesian-English translators made was in deviation of meanings, it was more than half $(58,67 \%)$ of the total translation errors.
\end{abstract}

Keywords: Translation, errors, crowdsourcing, application, Indonesian-English

\section{INTRODUCTION}

Translation has a great role in the history of human social life. Recently its role has been greater by the overwhelming developments in communication technology. The most recent and popular development in translation is crowdsourcing translation, the term 'crowdsourcing' was coined by Howe (2008) 'Crowdsourcing is the act of taking a job 
traditionally performed by a designated agent (usually an employee) and outsourcing it to an undefined, generally large group of people in the form of an open call'. Crowdsourcing is developing fast and expanding to a rapidly growing number of areas, which also include translation where it has lately become a hot topic.

Crowdsourcing translation has many benefits. Anastasiou (2011) stated as follows 'the first benefit is translation prosumption, it is not the translator who projects a target-oriented model of translation on to an audience, but the audience producing their own selfrepresentation as a target audience. Second is post-print translation literacy, as the technological world is moved today by the printing press to the electronic computer, reading practices and literacy norms change. And the third is translation and plurisubjectivity, in crowdsourcing we can find reinvestment of translation technology to further human concerns or agendas.'

At the same time, concerns also raised about crowdsourcing in general also apply in the case of translation. Worries are voiced in the quality of the work done in this way. There is a fear that this new method to a certain extent still untested. It raises doubts concerning the standard of the output, there are doubts in how quality and confidentiality be ensured when authorship becomes a vague concept and traceability is difficult to enforce.

Crowdsourcing translation platform is a human-based translation. It requires translators. If the translator did not master translation theories, the result of translation would have errors. Translation errors may have some undesirable results. Sakri in Huda (1995), contend that the scarcity of qualified translators has got worse as the majority of translation services are provided by non-trained translators, they are mostly students of English departments. They become translators just because they know English, not because they are trained to pursue their career in translation.

Based on all the statements above, the researcher is interested in finding out what kinds of translation errors especially in Indonesian-English translation that is occurred in crowdsourcing translation application. The objectives of this investigation were to find out: 1) Kinds of translation errors made by Indonesian-English Translators in Crowdsourcing Translation Apllication. And 2) Dominant kind of translation error made by IndonesianEnglish Translators in Crowdsourcing Translation Apllication.

The result of the research, theoretically, will give detail information about all kinds of translation errors made by Indonesian-English translators in crowdsourcing translation apllication. And practically, it will be a useful information specially for Indonesian-English translator, to aware Indonesian-English translators especially the novice ones, not to commit those errors in their translations. Also as a base-reference for the next researcher who is interested to establish an investigation in the same area.

\section{REVIEW OF RELATED LITERATURE}

\section{Translation Definition}


Brislin (1976) defined translation as a complex process of transferring thoughts and ideas from one language to another, whether the languages are written or oral forms. It is supported by Nida and Taber (1974) who state that the process of translation is reproducing in the receptor language the closest natural equivalence of the source language message, first in terms of meaning and secondly in terms of style.

Catford (1974) has a different definition of translation. He stated that the translation is the replacement of textual material in one language by the equivalent textual material in another language.

Newmark (1988) had another definition of translation, "It is rendering the meaning of a text into another language in the way that the author intended the text."

To sum up, translation is the process of reproducing message from one language (SL) with the closest natural equivalence of another language (TL), in written or in oral form, first in terms of meaning and secondly in terms of style.

\section{Translation Process}

Translation process is a model which is used to describe thinking process did by translator when translating something.

Suryawinata (1989) viewed translation process as a linear translation process, translator directly rewrite text in source language into the target language. Nida and Taber (1974), on the contrary, described translation process as a dynamic process. In the dynamic translation, there are three steps namely analysis, transfer, and restructuring. In analysis step, translator analyze the text in source language. The things to be analyzed are the structure of the text and the meaning of words, phrases, and sentences to understand the meaning of the whole text. After understanding the meaning in source language, translator transferring the meaning into the target language in her mind. Finally, in restructuring step, translator reproduce the meaning into the target language based on the rules of the target language.

Larson (1984) also proposed a model of translation process. In general, the model is similar to Nida and Taber's model. However, Larson does not include transferring process in his model. According to Larson, translation process consists of studying and analyzing words, grammatical structure, situation, and cultural context in source language in order to understanding the meaning being delivered by the text. After that, translator reconstruct the meaning in source language by using words and structures in target language.

\section{Translation Strategies}

Translation strategy is ways or procedures engaged by translator in translating words, phrases, or sentences into target language. Furthermore, Newmark (1988) called translation strategies as a translation procedures. He defined translation procedure as the process of 
transferring sentences and the smaller unit of language in source language into target language.

According to Suryawinata (1989), translation strategy is divided into two main types. First is related to the sentence structures which is called structural strategy. Structural strategies mostly have to be done by translator. If he/she does not use those strategies, the translation text will be ungrammatical and not acceptable in target language. Second type is related to the meaning of the text being translated.

\section{Translation Errors}

Errors in simple words are the problematic aspects of learners. They are some segments of the text or speech which depart from the accepted norms of any specific language. Since norms are general phenomenon common to all languages, novice translators as language learners cannot provide a text without systematical errors (Dulay, Burt, \& Krashen, 1982).

The fundamental cause for making translation errors is social, psychological and linguistic interactions which challenge even the most professional translators (Pojprasat, 2007). A translation error is illustrated as "What rightly appears to be linguistically equivalent may very frequently qualify as 'translationally' nonequivalent." (Neubert \& Shreve, 1992).

According to Pinker (1986) cited in Jahanshahi and Kafipour (2015) determining the steps for a proper error analysis as a tool, would help to identify the weaknesses of the analysis. The first step of error analysis according to Pinker (1986) is collecting appropriate sample from the language. The second step is detecting the errors in the sample. In this regard, as believed by some scholars, errors have different levels. The third step is related to the identification of an error and its description as well. This step for error analysis brings about a lot of problems because there's no well-defined and universal criterion for an error in linguistic categorizations. The fourth step is classifying the errors based on their hypothesized cause.

Akil (2007) in his thesis, specified five kinds of translation errors, namely: (1) inversion of meaning: the expression of meaning of the source language text in another way round. In this case, the target language's intention contradicts with that of source language; (2) addition of meaning: the inclusion of intentions or ideas which are not mentioned or implied in the source language. In the other word, the intention of the source language is broadened; (3) omission of meaning: the exclusion of idea or ideas of the source language in the target language, so that the intention of the source language is not completely transferred; (4) deviation of meaning : the diversion of the intention of the source language to other notions; (5) modification of meaning: the expression of the intention of the source language into an unclear form. This research will be analyzed based on the error taxonomy from (Akil, 2007)

\section{Crowdsourcing Translation}

Crowdsourcing is a new model that opens the way for collaborative processes. The term 'crowdsourcing' was first coined by Howe (2008), he defined it as follows: 'Crowdsourcing is the act of taking a job traditionally performed by a designated agent 
(usually an employee) and outsourcing it to an undefined, generally large group of people in the form of an open call'. Crowdsourcing translation is the existence of a platform and a volunteer community/crowd willing to translate with low payment (if any) content which is submitted online (Anastasiou, 2011). Crowdsourcing translation mainly focus on translation of text only and not of text existent in multimedia, or translation networks and wikis.

\section{METHOD OF THE RESEARCH}

The researchers used a descriptive qualitative research with the strategy of case study in which analyzing the errors that translators made on translating Indonesian texts (source language texts) into English texts (target language texts) in crowdsourcing translation application. The subject of the research was Indonesian-English translators in crowdsourcing translation application of flitto. Purposive sampling technique will be adopted in this research to select the sample.

The instrument used for this research was 50 Indonesian texts that is requested to be translated into English by users of Flitto and all of its English translations made by the Indonesian-English translators in Flitto. Furthermore, to ensure uniformity, correct and consistent evaluation of the translators' translation, a translation model (key) to each text was prepared with the assistance of two competent Indonesian-English bilinguals.

To obtain the data, the researcher signed up to crowdsourcing translation application of Flitto, then the researcher collected data of translations in flitto selectively. The researcher only took translation request from Indonesian to English in form of text only. Furthermore, the researcher only chose 50 translation requests in form of texts that had 1 sentence to 3 sentences and translated to English by minimal 5 translators. The researcher made this limitation in order to avoid the data was being to diverse. And after all the data of translations were fully collected, the data in form of screenshots of the translation requests and its translations were analyzed.

The data collected from crowdsourcing translation application was analyzed by using error analysis technique of Miles and Huberman (1984) consisted of three stages: data reduction, data display and conclusion /verification.

\section{FINDINGS}

1. Translation variation and frequency of translation errors made by Indonesian-English Translators in Crowdsourcing Translation Application

The research revealed that there are 50 source language (SL) texts from Indonesian-English translation request in crowdsourcing translation application apps. Those 50 texts were translated by 353 into 350 variations of translation in total. Frequency of translation errors on the target language texts made by translators can be described by the chart below: 


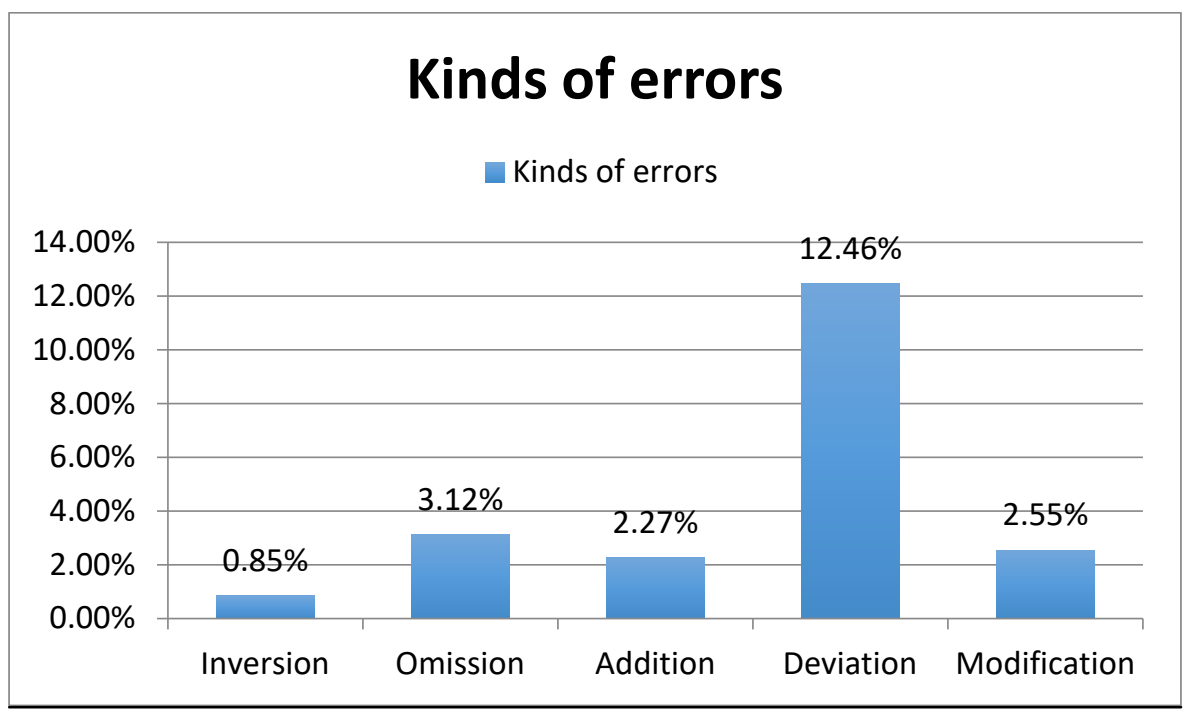

The chart above shows that from 75 translations errors made by Indonesian-English translators, $4 \%$ of those errors were in inversion of meaning, $15 \%$ in omission of meaning, $11 \%$ in addition of meaning, $58 \%$ in deviation of meaning and $12 \%$ in modification of meaning. Dominant errors made by Indonesian-English translators were in deviation of meaning, it's more than half of the entire translation errors made by the translators.

\section{Translation errors on inversion of meaning}

Inversion of meaning is the expression of meaning of the source language text which the target language's intention contradicts with that of source language. There were 3 translation errors on inversion of meaning made by the translators.

\section{Translation errors on omission of meaning}

Omission of meaning is the exclusion of idea or ideas of the source language in the target language, so that the intention of the source language is not completely transferred. There were 10 translation errors on omission of meaning. These errors were happened because the translators did not transferred idea or ideas from source language to the target language. For instance:

SLT : Bisakah anda menungguku disini?

TLT : Can you wait for a while, please?

TL-Key :Could you wait for me here for a while?

On the example above, the translator forgot to include the idea of "disini" into the target language. So the appropriate translation should be "Could you wait for me here for a while?

4. Translation errors on addition of meaning 
Addition of meaning is the inclusion of intentions or ideas which are not mentioned or implied in the source language. There were 6 translation errors on addition of meaning. For instance:

\section{SLT : Analisis faktor-faktor yang mempengaruhi hasil produksi jagung di kabupaten Karo. \\ TLT : Analysis on factors that possibility affect the result of the corn production in Karo Regency. \\ TL-Key :An analysis of factors that affect corn production in Karo Regency.}

On the example above, the translator added the idea of "possibility" which is not mentioned in the source language into the target language. In order to make the translation transferred the original intention of the source language, the appropriate translation should be "An Analysis of factors that affect corn production in Karo Regency."

\section{Translation errors on deviation of meaning}

Deviation of meaning is the diversion of the intention of the source language to other notions. There were 44 translation errors on deviation of meaning. For instance:

\section{SLT : Sampah yang sangat berbahaya bagi masyarakat \\ TLT : Trash is so dangerous for society

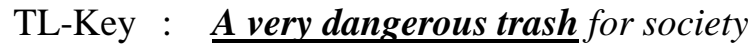

On the example above, the idea of "sampah yang sangat berbahaya" in the source language is changed into "sampah sangat berbahaya" by using sentence "Trash is so dangerous" in the target language. The phrase "sampah yang sangat berbahaya" has the equal meaning with "A very dangerous trash" in the target language. The sentence "a very dangerous trash" shows that there were specific trash that is very dangerous. Meanwhile "trash is so dangerous" shows that all trash is very dangerous. In order to make the translation transferred the original intention of the source language, the appropriate translation should be "A very dangerous trash for society"

\section{Translation errors on modification of meaning}

Modification of meaning is the expression of the intention of the source language into an unclear form. There were 11 translation errors on modification of meaning. For instance:

SLT : Bosan dengan semua rutinitas

TLT : Feeling bored with all of the routinities

TL-Key : Bored with all the routines

On the example above, the translator translated "rutinitas" into "routinities" in the target language text. There is no word "routinities" in English, thus it make the translation into an unclear form. This error may be occurs due to overgeneralisation. It is the application of a grammatical rule in cases where it doesn't apply. In order to make the intention of the 
source language into clear form, the appropriate translation should be "Bored with all the routines.

\section{DISCUSSION}

Data for this research were collected from 50 Indonesian translation requests and its english translation in crowdsourcing translation application. In collecting data, the researcher adopted purposive sampling technique to select the sample. The criteria of the sample is 50 translation requests in form of texts that contain 1 sentence to 5 sentences and translated to english by minimal 5 translators. The researcher made this limitation in order to avoid the data is being to diverse. Moreover, the reason why the researcher is choosing translations translated by minimal 5 translators is by that the researcher can optimally view data variations and translation errors for each translated source language text. The source of data collection were different from all the researchers that has been mention previously in chapter 2. Source of data in thesis of Akil (2007) were taken from Indonesian-English translations made by English Department students of higher learning institutions in Makassar. Source of data on Saleh (2007) were taken from translators residing in Makassar. Rimari (2010) and Sadiyani (2011) took data from Indonesian book and its english translation. On the other hand, the research took data from the Indonesian-English translators on crowdsourcing translation application.

Based on the data finding, there are 353 target language texts which are translated from 50 source language texts, from those target language texts, there are 350 variations $(99,15 \%)$ of translation in total. averagely there was 139 translation (TL-Text) variations for each text. This finding is in line with what Akil revealed in his study (2007). His study revealed that level of variation was very high (81\%), averagely there was 139 translation (TL-Text) variations for each sentence of the translated passages.

Dominant kind of translation error made by the translators were on deviation of meaning. $58.67 \%$ of translation errors were due to deviation of meaning. This finding is in line with what Akil revealed in his study (2007). He found that there were two kinds of translation errors mostly made by the students, they were modification of meaning and deviation of meaning. It is also supported by Setiawan (2014), he found that failure in choosing appropriate words dominates the occurrence of errors in translation. The failure can led to deviation of meaning in the target language text.

\section{CONCLUSION}

The research concludes that the Indonesian-English translators made all kinds of translation errors in translating the source language text into the target language text. Dominant translation errors that the the translators made were deviation of meanings. There were 44 $(12.46 \%)$ translation errors in deviation of meaning.

\section{SUGGESTIONS}


1. For the translators, Indonesian-English translators in crowdsourcing translation app are suggested to read more about translation theory to improve their understanding of the nature and the process of translation. As the translation errors made by the translators due to mistake in word choice, the translators also suggested to read more dictionary, both monolingual and bilingual dictionary.

2. For the administrator of crowdsourcing translation application, it is suggested to further tighten the translator entrance test, so that the quality of the translators is higher.

3. For the Other Researcher, one of the limitations of this study is not intensive and comprehensive enough in revealing the source of translation errors. Therefore, other interested researchers are suggested to conduct a study on it.

\section{REFERENCES}

Akil, M. 2007. The Profile of Indonesian - English Translation Made by English Department Students of Higher Learning Institutions in Makassar. (Postgraduate), Hasanuddin University.

Ambawani, S. 2014. Grammatical Errors On Indonesian - English Translation By Google Translate.

Anastasiou, D. 2011. Crowdsourcing as Human-Machine Translation (HMT). Journal of Information Science, 1-25.

Brislin, R. W. 1976. Translation: Application and Research. New York: Gardner Press Inc.

Catford, J. C. 1974. A Linguistic Theory of Translation. London: Oxford University Press.

Chandler, D., \& Munday, R. 2016. A Dictionary of Media and Communication (2 ed.): Oxford University Press.

Dulay, H., Burt, M., \& Krashen, S. 1982. Language two. Oxford: Oxford University Press.

Howe, J. 2008. Crowdsourcing, Why the power of the crowd is driving the future of business. New York: Crown Publishing Group.

Huda. 1995. Errors Made by the Students in Translating English Text into Indonesian. Universitas Bung Hatta, Unpublished Thesis.

Jahanshahi, M., \& Kafipour, R. 2015. Error Analysis of English Translation of Islamic Texts by Iranian Translators. Journal of Applied Linguistics and Language Research, 2(3).

Larson, M. L. 1984. Meaning-based translation: A guide to cross-language equivalence. Lanham, MD: University Press of America. 
Miles, M. B., \& Huberman, A. M. 1984. Analisis Data Kualitatif (T. R. Rohidi, Trans.). Jakarta: Universitas Indonesia.

Neubert, A., \& Shreve, G. M. 1992. Translation as Text. German: Kent State University Press.

Newmark, P. 1988. A Textbook of Translation. Hertfordshire: Prentice Hall Elt Europe.

Nida, E. A. 1964. Toward A Science of Translating. Leiden: E.J. Brill.

Nida, E. A., \& Taber, C. R. 1974. The Theory and Practice of Translation. Leiden: E. J. Brill.

Pojprasat, S. 2007. An Analysis Of Translation Errors Made By Mattayomsuksa 6 Students Srinakharinwirot University.

Rimari, Z. 2010. A Translation Analysis Of Indonesian Material Cultural Terms In "Tenun Ikat" And In The English Translation "Indonesian Ikats". Sebelas Maret University.

Sadiyani, N. W. 2011. The Translation of Indonesian Passive Voice Into English With Reference to "Bawang Merah Dan Bawang Putih" And It's Translation 'Miss Onion And Miss Garlic'. (Postgraduate), Udayana University.

Saleh, N. J. 2007. The Linguistic Competence Of Indonesian Translators In Translating Englis Texts Into Indonesian Language: With Special Reference To Translators In Makassar. (PhD), Hasanuddin University.

Setiawan, Y. 2014. English Translation Errors in Abstracts of Educational Administration Students of Post Graduate School of State University of Medan. JOURNAL OF EDUCATION, 7.

Sobol, F. J. 2012. Translation in Transition: The Feasibility and Effectiveness of Crowdsourced Translation Versus Professional Translation. University of Arizona.

Suliman, M. 2013. An Analysis of The Translation of The Idiomatic Expressions Used In The Subtitles of Tangled. Wijaya Putra University.

Suryawinata, Z. 1989. Terjemahan Pengantar Teori dan Praktek. Malang: Depdikbud.

Waddington, C. 2001. Different Methods of Evaluating Student Translation: The Question of Validity.

Widyamarta, A. 1989. Seni Menerjemahkan. Yogyakarta: Kanisius. 